\title{
Editorial: Sarel van der Merwe
}

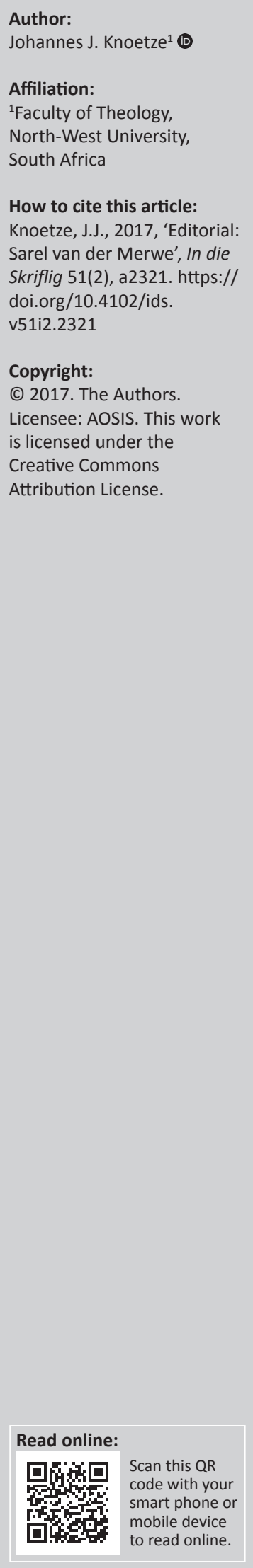

This publication is the compilation of 11 research articles in which authors from different theological disciplines and perspectives reflected on the influence of the missio Dei. Most of the authors are colleagues of Prof. Sarel van der Merwe or were influenced by his burning passion for the missio Dei. Within this publication the richness of the missio Dei is presented in the uniqueness of each article from different subject fields and themes. Three of the articles are written in Afrikaans with the remaining eight written in English.

Herrie van Rooy wrote an Afrikaans article from the Old Testament, entitled 'The missio Dei and the study of the Old Testament'. This article focuses on the study of the Old Testament and its role and message for the mission of the church as well as theological training. After focusing on certain aspects of the missio Dei from Old Testament examples, the Book of Ezekiel is used as example to contribute to the understanding of the missional task of the church.

Four of the articles come from Sarel's field of expertise - the subject field of missiology. Hannes Knoetze gives a historical overview of the development of missiology as subject field following the main mission conferences over the last century. In his article 'A long walk to obedience: Missiology and mission under scrutiny (1910-2010)' he attends to the question: What does it mean to be obedient to the mission calling in a broken and traumatised world? Pieter Verster also wrote an Afrikaans article, titled 'The missional church in communities in informal settlements' where the social challenges, related to the massive urbanisation are discussed. The centrality of Jesus Christ, within the holistic view of the missio Dei, is emphasised to empower these communities with hope. In another Afrikaans article, titled 'The need of cultural interaction in Apologetics: Acts 17:16-32 as explanatory statement', Johan Erasmus and Henk Stoker attend to the secular versus holy dualism. It is argued that to be culturally effective, apologists should make use of images and expressions that are familiar to the people they aim to reach. The images used in the arts and especially films can be of great help to apologists in this regard. Acts 17 is used as an example of how Paul subverts Greek ideas by putting them in a monotheistic context. A second article related to apologetics is presented by Henk Stoker and Paul Derengowski in relation to Surah 2:4 of the Koran which requires Moslems to believe in the Bible. In this article, titled 'A discussion about the version of the Bible available to Muhammad', a response is offered to Muslim apologists who rejected the statement, because they believe the Bible is corrupt.

It is a well-known fact that the missio Dei is closely linked to the covenant and God's kingdom. In his article, 'Kingdom, covenant, and human rights', Koos Vorster writes from the dogmatic or ethics discipline about human rights based on the revelation history. From a hermeneutics of trust the concepts of kingdom and covenant are used as a foundation for a Christian theory of human rights, both as legal and moral human rights. As both these concepts, kingdom and covenant, are essentially about justice and relationships between God and humankind, between people and their neighbours, and between humans and creation, these relations are the essence of the human rights people have.

Three contextual articles with a focus on Africa were written within the field of pastoral care. In her article 'The cultural aspect in the contextualisation of pastoral caregiving ministry', Amanda $\mathrm{du}$ Plessis attends to the research question on the interwovenness between the Christian faith and the different cultures of the people of South Africa. She discusses the compatibility and/or incompatibility of Western and African cultures, and concludes with the principles of a Christian culture and its implications for the pastoral caregiving. In the next article in this subject field, titled 'Brothers and sisters, can you hear us? Remarks on facilitating a productive dialogue between the Western and African notions of practical theology in light of the decolonisation discourse', Alfred Brunsdon gives an overview of Lartey's work Postcolonializing God - An African practical theology (2013). His conclusion is that decolonisation is of restricted use in the design of Western practical theology, while it provides insight into an authentic African practical theology. This article suggests an inter-contextual dialogue. In this regard the notion of Esther Acolatse's 
pastoral hermeneutic of primal speech is introduced to provide valuable parameters for such a dialogue. Vhumani Magezi \& Collium Banda wrote the third article in the field of pastoral care, titled 'Competing with Christ? A critical Christological analysis of the reliance on Pentecostal prophets in Zimbabwe'. The domineering and mediatory role of the Pentecostal prophets within the Zimbabwean context are analysed from an Christological perspective. Instead of leading people to depend only on Christ for their spiritual security and prosperity, Pentecostal prophets present themselves as super spiritual authorities who must be relied upon by the believers in addition to Christ and who are uniquely anointed by God. With this they imply that they are closer to God than other people and, in turn, they receive spiritual power and authority over other believers. This article aims to empower believers to distance themselves from these prophets and their disturbed image of Christ.

The last two articles were written from a New Testament perspective. In 'A fruitful missional exegesis for a missional hermeneutic and missiology', Timothy van Aarde and Fohle Lygunda Li-M describe a missiological exegesis in which text and context are interrelated. Both the context and the text must determine the missiological strategy. Neither the text nor the context is emphasised at the exclusion or expense of the other. The last article in this special edition, titled 'A rediscovery of the priesthood of believers in Ephesians 4:116 and its relevance for the Missio Dei and a biblical missional ecumenism' was written by George Lotter and Timothy van Aarde. The role of the laity in the missio Dei was one of the most significant developments. The article considers the rediscovery of the priesthood of all believers in the different church denominations with its biblical foundation in Ephesians 4 and other scriptures.

To conclude: Thank you to every author who participated in this publication and, as such, gave recognition to Sarel van der Merwe for his work in God's kingdom and his participation in the missio Dei. I pray that these articles will inspire others to surrender with more passion to participate in the missio Dei. 'The harvest is plentiful but the workers are few'.

Soli Deo Gloria. 